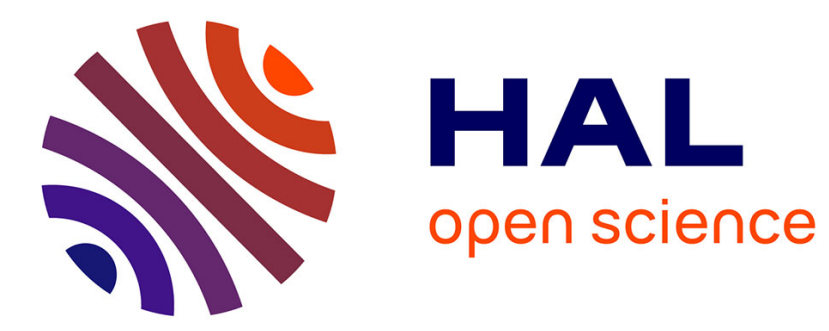

\title{
Patterns of Care and Outcome Radiation-Induced Soft Tissue Sarcomas
}

\author{
Antoine Italiano, Solène Bringer, Jean-Yves Blay, Sylvie Bonvalot, Axel Le
} Cesne, Francois Le Loarer, Phillipe Maingon

\section{To cite this version:}

Antoine Italiano, Solène Bringer, Jean-Yves Blay, Sylvie Bonvalot, Axel Le Cesne, et al.. Patterns of Care and Outcome Radiation-Induced Soft Tissue Sarcomas. International Journal of Radiation Oncology, Biology, Physics, 2019, 103, pp.449 - 452. 10.1016/j.ijrobp.2018.09.028 • hal-03486846

\section{HAL Id: hal-03486846 \\ https://hal.science/hal-03486846}

Submitted on 20 Dec 2021

HAL is a multi-disciplinary open access archive for the deposit and dissemination of scientific research documents, whether they are published or not. The documents may come from teaching and research institutions in France or abroad, or from public or private research centers.
L'archive ouverte pluridisciplinaire HAL, est destinée au dépôt et à la diffusion de documents scientifiques de niveau recherche, publiés ou non, émanant des établissements d'enseignement et de recherche français ou étrangers, des laboratoires publics ou privés.

\section{다)(1) $(5$}

Distributed under a Creative Commons Attribution - NonCommerciall 4.0 International 


\section{Scientific Letter}

\section{Patterns of care and outcome Radiation-Induced Soft Tissue Sarcomas}

Short title: Outcome of radiation-induced soft-tissue sarcomas

Italiano $\mathrm{A}^{1,2}, \mathrm{MD}$; Solène Bringer ${ }^{2,3}, \mathrm{MD}$; Blay $\mathrm{JY}^{4}, \mathrm{MD}$; Bonvalot $\mathrm{S}^{5}$, MD; Le Cesne $\mathrm{A}^{6}$, $\mathrm{MD}$; Le Loarer $\mathrm{F}^{7}$, MD; Maingon $\mathrm{P}^{8}, \mathrm{MD}$.

${ }^{1}$ Department of Medical Oncology, Institut Bergonié, Bordeaux, France.

${ }^{2}$ University of Bordeaux, France

${ }^{3}$ Department of Raditoherapy, Institut Bergonié, Bordeaux, France

${ }^{4}$ Department of Medical Oncology, Centre Léon Berard, Lyon France

${ }^{5}$ Department of Surgery, Institut Curie, Paris, France

${ }^{6}$ Department of Medical Oncology, Institut Gustave Roussy, Villejuif, France

${ }^{7}$ Department of Pathology, Institut Bergonié, Bordeaux, France

${ }^{8}$ Department of Radiation Oncology, Sorbonne University, HU La Pitié Salpêtrière Charles Foix, Assistance-Publique des Hôpitaux de Paris, Paris, France

\section{Corresponding author:}

$\operatorname{Pr}$ Antoine ITALIANO, MD, $\mathrm{PhD}$,

Department of Medical Oncology, Institut Bergonié, Comprehensive Cancer Centre, 229 cours de l'Argonne, 33076 Bordeaux, France

05.56.33.32.44

E-mail: a.italiano@bordeaux.unicancer.fr

\section{Conflicts of Interest: None}

Financial Support/Funding Statement: Institut Bergonié

\section{Word count: 794 words}




\title{
Scientific Letter
}

\section{Patterns of care and outcome of Radiation-Induced Soft Tissue Sarcomas}

\begin{abstract}
More than half of all cancer patients receive radiotherapy. With the increasing number of long-term cancer survivors, there is a growing concern about the risk of radiation induced second malignant neoplasm. Sarcomas represent the most frequent type of cancer than can be induced by radiation exposure. We report the largest series of radiation-induced sarcomas (RIS). We demonstrate that a majority of RIS can be cured, provided they underwent wellplanned surgery.
\end{abstract}




\section{Introduction}

Radiation therapy is used as a treatment for many cancers, alone or in combination with other treatment modalities such as chemotherapy and surgery. However, radiation exposure is a well-established risk factor for secondary malignancies, soft-tissue sarcomas (STS) being the most common tumor type occurring in this setting. Only limited data regarding the incidence, clinical characteristics, outcome and prognostics factors of radiation-induced STS (RIS) are available in the localized and advanced settings (1-2).

\section{Methods}

Between January 1, 1990, and December 31, 2013, 19449 adult patients were identified from a prospective French Sarcoma Group Database. There were 510 patients $(0.03 \%)$ identified with radiation-induced sarcomas (RIS), which were defined as (i) history of radiation exposure at least 6 months before the development of sarcoma (3), (ii) occurrence of sarcoma within the radiation field, and (iii) pathologic confirmation of a sarcoma histologically different from the primary cancer. Bone sarcomas were excluded from the study. Margin status was defined as previously described with the R system (4). Prognostic factors for locoregional-free survival (LRFS), metastases-free survival (MFS) and overall survival (OS) were planned to be identified by univariate and multivariate analyses using a Cox regression model. Variables tested in univariate analysis included: age (median:66 years), gender, histological subtype, grade, tumor size (median: $55 \mathrm{~mm}$ ), tumor depth, tumor location, margin status and presence of a lymphodema. Variables associated with with a p-value $<0.05$ in the univariate analysis were planned to be included in the multivariate analysis. Analyses were performed using SPSS 18.0 statistical software (IPSS Inc., Chicago, USA). All statistical tests were two-sided, and $\mathrm{p}<0.05$ indicated statistical significance. 


\section{Results}

Patient characteristics are summarized in Table 1. The most common histologic type was angiosarcoma followed by undifferentiated pleomorphic sarcoma. 31 patients $(6 \%)$ had synchronous metastases at diagnosis. For the 479 patients with non-metastatic disease, 256 patients (53.4\%) were treated solely with surgical resection, 148 (30.9\%) received neoadjuvant/adjuvant chemotherapy, and $42(8.8 \%)$ were treated with neoadjuvant/adjuvant radiotherapy. 33 patients had unresectable tumors and did not underwent surgery. On multivariate analysis, the main factors significantly associated with unresectability were male gender $(\mathrm{OR}=1.9$ IC95\% [1.1-3.4] $\mathrm{p}=0.03)$, tumor site outside of trunk wall $(\mathrm{OR}=2.01$ [1.23.4] $\mathrm{p}=0.008)$, tumor size $>55 \mathrm{~mm}(\mathrm{OR}=4.2[2.3-7.9] \mathrm{p}<0.0001)$, and presence of a lymphedema $(\mathrm{OR}=5.9[2.6-13.1] \mathrm{p}<0.0001)$.

Median follow-up was 62.9 months [55.0-73.0].

Median LRFS for M0 patients with R0/R1 surgery was 41.2 months 95\% [33.7-112.9]. 5-year and 10 year LRFS rates were $47.2 \%$ [41.2-52.9] and 42.1\% [35.0-49.1] respectively. On multivariate analysis, the independent predictors of worse LRFS were age > 66 years $(\mathrm{HR}=1.5$ [1.1-2.1], $\mathrm{p}=004)$, angiosarcoma $(\mathrm{HR}=1.3$ [1.2-1.9], $\mathrm{p}=0.001)$, tumor size $>55 \mathrm{~mm}$ $(\mathrm{HR}=1.2[0.8-1.7], \mathrm{p}<0.0001$, and $\mathrm{R} 1$ margin status $(\mathrm{HR}=1.6[1.2-2.3], \mathrm{p}<0.0001)$.

Median MFS for patients with R0/R1 surgery was not reached. 5-year and 10-year MFS rates were $66.2 \%$ [60.2-71.4] and $60.5 \%$ [53.0-67.2] respectively. On multivariate analysis, the independent predictors of worse MFS were grade $3(\mathrm{HR}=3.4 \mathrm{IC} 95 \%$ [1.5-7.8], $\mathrm{p}<0.001)$ and R1 margin status $(\mathrm{HR}=1.8$ IC95\% [1.2-2.7],p=0.002). Peri-operative chemotherapy did not influence MFS $(\mathrm{p}=0.5)$. 
Median overall survival for patients M0 with R0/R1 surgery was 65.1 months 95\% [50.098.4] The 5-year and 10-year OS rates were $52.9 \%$ [47.1-58.2] and 41.0\% [34.2-47.7] respectively. On multivariate analysis, the predictors of worse OS were age > 66 years $(\mathrm{HR}=1.4 \mathrm{IC} 95 \%$ [1.02-1.93] p=0.04), R1 margin status $(\mathrm{HR}=1.8 \mathrm{IC} 95 \%$ [1.3-2.5] $\mathrm{p}<0.001)$, grade $3(\mathrm{HR}=1.9 \mathrm{IC} 95 \%$ [1.1-3.4] $\mathrm{p}=0.02)$ and size > 55mm $(\mathrm{HR}=1.6 \mathrm{IC} 95 \%$ [1.1-2.2] $\mathrm{p}=0.02)$ (Figure 1).

162 patients had metastases at diagnosis or during follow-up. $85(52.5 \%)$ of them received $\geq 1$ line of chemotherapy, $47 \geq 2$ lines of treatment and 21 patients $\geq 3$ lines or more. 9 patients did not receive any systemic treatment. Median time to next treatment was 3.5 months [2.75.4] and 2.9 [2.3-5.0] in the 1st line and 2nd line setting respectively. Polychemotherapy was significantly associated with improved time to subsequent-treatment in the 1st and 2nd line settingMedian oOverall survival of patients with metastatic disease was 8.2 months $95 \mathrm{Cl}$ [6.4-10.4].

\section{Discussion}

Previous studies based on small series suggested that RIS have a poor sarcoma-related survival with 5-year overall survival ranging from 10 to $36 \%$ (1-2). With a 5-year OS for patients with R0/R1 surgery of $52.9 \%$, our study demonstrates that a significant proportion of patients with RIS can be cured, provided they underwent well-planned R0 surgery which represent a major independent predictor of death. This result emphasizes the need to refer patients with RIS to expert surgeons applying the same standard surgical procedures as for other sarcoma patients.

The risk of metastatic relapse remains high occurring in up to $33 \%$ of patients. Two recent studies have shown the positive significant impact of neoadjuvant systemic therapy on the reduction of the risks of metastatic relapse and death. However, none of them included 
patients with RIS (5-6). In our series, 148 (30.9\%) patients received peri-operative chemotherapy without any impact on MFS or OS suggesting a relative resistance to chemotherapy. Such resistance is also illustrated by the very poor outcome of RIS in the metastatic setting (8.2 months) in comparison with sporadic soft-tissue sarcomas (12-18 months) (7).

Altogether, our results indicate that patients with RIS should be managed with the same curative intent than patients with sporadic STS. Given the limited benefits of cytotoxic drugs currently used for the management of STS, future studies investigating the biology of RIS are warranted to identify the mechanisms involved in their development and their therapeutic vulnerabilities to improve outcome.

\section{References}

1. Lagrange JL, Ramaioli A, Château MC, Marchal C, Resbeut M, Richaud P, et al. Sarcoma after radiation therapy: retrospective multi-institutional study of 80 histologically confirmed cases. Radiology 2000;216:197-205

2. Pitcher ME, Davidson TI, Fisher C, Thomas JM. Post-irradiation sarcoma of soft tissue and bone. Eur J Surg Oncol 1994; 20:53-6.

3. Gladdy RA, Qin LX, Moraco N, Edgar MA, Antonescu CR, Alektiar KM, Brennan MF, Singer S. Do radiation-associated soft tissue sarcomas have the same prognosis as sporadic soft tissue sarcomas? J Clin Oncol. 2010;28:2064-9.

4. Gundle KR, Kafchinski L, Gupta S, Griffin AM, Dickson BC, Chung PW, Catton CN, O'Sullivan B, Wunder JS, Ferguson PC. Analysis of Margin Classification Systems for Assessing the Risk of Local Recurrence After Soft Tissue Sarcoma Resection. J Clin Oncol. 2018; 36:704-709. 
5. Issels RD, Lindner LH, Verweij J, Wessalowski R, Reichardt P, Wust P, et al. Effect of Neoadjuvant Chemotherapy Plus Regional Hyperthermia on Long-term Outcomes Among Patients With Localized High-Risk Soft Tissue Sarcoma: The EORTC 62961ESHO 95 Randomized Clinical Trial.JAMA Oncol. 2018 Feb 15.

6. Gronchi A, Ferrari S, Quagliuolo V, Broto JM, Pousa AL, Grignani G, et al. Histotype-tailored neoadjuvant chemotherapy versus standard chemotherapy in patients with high-risk soft-tissue sarcomas (ISG-STS 1001): an international, openlabel, randomised, controlled, phase 3, multicentre trial. Lancet Oncol. 2017;18:812822.

7. Savina M, Le Cesne A, Blay JY, Ray-Coquard I, Mir O, Toulmonde M, et al. Patterns of care and outcomes of patients with METAstatic soft tissue SARComa in a real-life setting: the METASARC observational study. BMC Med. 2017;15: 78.

\section{FIGURE LEGEND}

Figure 1. Kaplan-Meier curves of overall survival in patients with R0/R1 surgical resection of radiation-induced STS according to age (A), tumor size (B) and margin status (C). 


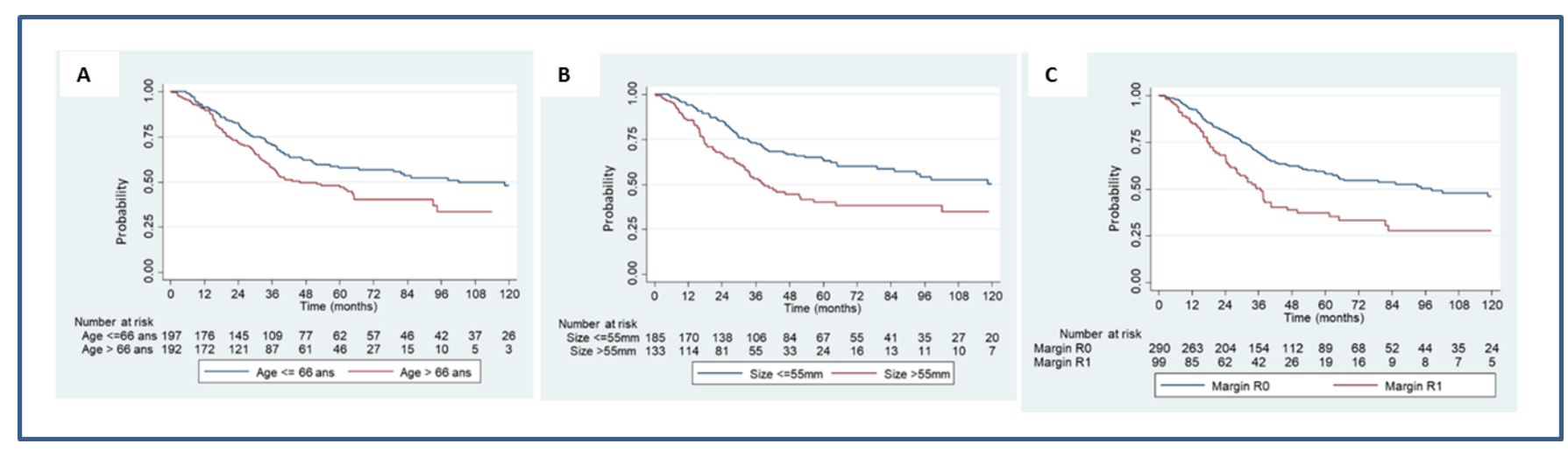

Figure 1. Kaplan-Meier curves of overall survival in patients with R0/R1 surgical resection of radiation-induced STS according to age (A), tumor size (B) and margin status (C). 
TABLE

\begin{tabular}{|c|c|c|}
\hline & \multicolumn{2}{|c|}{ Total } \\
\hline & $N(510)$ & $\%$ col \\
\hline \multicolumn{3}{|l|}{ Sex } \\
\hline Female & 412 & 80.8 \\
\hline Male & 98 & 19.2 \\
\hline \multicolumn{3}{|l|}{ Age_at_diagnosis } \\
\hline Median & 66.0 & \\
\hline Minimum & 15.0 & \\
\hline Maximum & 93.0 & \\
\hline \multicolumn{3}{|l|}{ Site_of_tumour_sub_category } \\
\hline Head and neck & 50 & 9.8 \\
\hline Internal trunk & 51 & 8.0 \\
\hline Lower limb & 37 & 5.1 \\
\hline Others & 31 & 6.1 \\
\hline Trunk wall & 294 & 57.6 \\
\hline Upper limb & 47 & 7.1 \\
\hline \multicolumn{3}{|l|}{ Depth_of_tumour } \\
\hline Deep & 221 & 43.3 \\
\hline Superficial & 194 & 38.0 \\
\hline Superficial and deep & 93 & 18.2 \\
\hline \multicolumn{3}{|l|}{ Size_of_tumour_mm } \\
\hline Median & 55.0 & \\
\hline Minimum & 6.0 & \\
\hline Maximum & 380.0 & \\
\hline \multicolumn{3}{|l|}{ Nodes involvement } \\
\hline No & 501 & 98.2 \\
\hline Yes & 9 & 1.8 \\
\hline \multicolumn{3}{|l|}{ Metastasis at diagnosis } \\
\hline No & 479 & 93.9 \\
\hline Yes & 31 & 6.1 \\
\hline \multicolumn{3}{|l|}{ Histological subtype } \\
\hline Angiosarcoma & 195 & 38.2 \\
\hline Undifferentiated pleomorphic & 172 & 33.7 \\
\hline Other & 143 & 28.0 \\
\hline \multicolumn{3}{|l|}{ Grade } \\
\hline 1 & 56 & 11 \\
\hline 2 & 175 & 34.3 \\
\hline 3 & 220 & 43.1 \\
\hline
\end{tabular}

